Review

\title{
DEVELOPMENT OF FRUIT SCIENCE IN LATVIA
}

\author{
Edīte Kaufmane*, Māra Skrīvele*, Edgars Rubauskis*, Sarmīte Strautina*, \\ Laila Ikase*, Gunārs Lācis*, Dalija Segliṇa*, Inga Moročko-Bičevska*, \\ Silvija Ruisa*, and Ilze Priekule** \\ * Latvia State Institute of Fruit-Growing, Graudu iela 1, Dobele LV-3701, LATVIA; \\ kaufmane@latnet.lv \\ ** Latvia State Plant Protection Centre, Struktoru iela 14, Rīga LV-1039, LATVIA
}

Contributed by Edīte Kaufmane

\begin{abstract}
Development of fruit growing and fruit science in Latvia has always been closely linked to the development of the whole country. After the founding of the independent Latvia state in 1918, fruit growing developed rapidly. Although in the Soviet times the situation was not favourable for quality fruit growing, research and breeding continued with good results. After Latvia regained independence, private land property rights were restored, and interest in intensive orchard establishment and growing technologies increased rapidly, which demanded change in the research focus. At present, the Latvia State Institute of Fruit-Growing is the leading institution in this field, working in cooperation with Püre Horticultural Research Centre, Latvian Plant Protection Research Centre, Institute of Agrobiotechology, and Faculty of Food Technology, Latvia University of Agriculture, Laboratory of Plant Mineral Nutrition, Institute of Biology, University of Latvia. Research is carried out in the following directions: breeding and cultivar evaluation; genetics and molecular biology; plant pathology and entomology; orchard management; experimental processing and storage.
\end{abstract}

Key words: breeding, growing technologies, pathogens, postharvest, genetics.

\section{INTRODUCTION}

Development of fruit growing and fruit science in Latvia has always been closely linked to the development of the whole country. History has shown that perennial crops can be grown successfully only if the land and property belong to the grower, and stability is ensured by succession of generations. Fruit growing expanded rapidly when the farmers obtained their own land. In the $19^{\text {th }}$ century, when Latvia was a part of the Russian empire, farmers obtained knowledge about orchard management and cultivars from manor orchards and nurseries, which propagated mostly cultivars popular in Western Europe that were poorly adapted to the Latvian climate.

After the founding of the independent Latvia state in 1918, fruit growing developed rapidly. In 1929, there were 29 state-funded bodies carrying out extension service for the growers. Orchard areas increased, processing of fruits and berries started and export of fruits and their products to Western Europe developed. This created the necessity and opportunity to establish a State Research Station in Pūre. As evaluation of cultivars was just started, each nursery propagated cultivars of their choice, mostly from Western Europe. Along with growing technologies introduced from countries with different climate, this was one of the reasons why in the following severe winters the greatest part of orchards, about 6 million trees, perished.

Development of fruit growing after the Second World War was greatly hindered by the abolishment of private land property, as well as loss of generation succession. Yet scientific research continued. A new Experimental Station was founded in Ogre, along with several support sites. Research was targeted more to yield quantity, not quality, as a significant processing industry had developed in Latvia. Later the specialisation of Latvia in the planning system of USSR was changed, supporting mostly stock farming. There were no possibilities to become acquainted with Western experience, and instead, wide cooperation with other Soviet researchers developed. Studies of growing technologies were carried out both for the needs of large state farms and home gardens. Variety evaluation focus was on the needs of home gardens, as only a few new orchards were established at the state farms.

After restoration of an independent Latvian state, interest in commercial orchards increased rapidly. Similarly to the 1930s, Western European cultivars and technologies had the main interest. Yet, as shown by experience of the last 
years, their introduction without preliminary trials can cause substantial financial loss. As the range of practical research needed by the growers is wide and should go on for years, while funding for such research is lacking, systematisation and evaluation of former research is crucial. Although the systems and production needs have changed, the soil, relief and climate remain the same.

According to the statistical data of Latvia Fruit Growers Association, in 2011 there were about 10000 ha commercial orchards. The main fruit crop is apple (over $4000 \mathrm{ha}$ ), main berry crops are strawberries (about 400 ha) and raspberries (300 ha). Areas of untraditional crops like Japanese quince, cranberries and blueberries are increasing.

Many of the established fruit plantations have already reached full yield, the growers have developed material base for production, and gained some experience in growing technologies, business management and marketing. Cooperatives are developing. As a result, during the latest years local fruits, berries and their products can be found not only in farmers markets, but also in supermarkets.

This paper reviews information about fruit growing research and its main results since the beginning of the $19^{\text {th }}$ century till today.

\section{RESEARCH IN THE $19^{\text {th }}$ CENTURY AND IN THE FIRST HALF OF $20^{\text {th }}$ CENTURY}

The first Latvian language book about fruit growing by J. H. Zigra (Cigra) was published in the same year as the first nursery was founded by him (Zigra, 1803; Daija, 2008). Later large nurseries were established in Rīga by C. H. Wagner and C. W. Schoch, and near Cēsis by A. von Sievers. The nurseries had pomological orchards where cultivars from Western Europe and Russia were planted and propagated. In 1871, a book Zemkopja auglu koku dārzs (Farmer's Orchard) was published by S. Klevers. Popularisation of fruit growing was done also by publicists like J. Penğerots-Svešais. Pomological descriptions of cultivars of Latvian origin have been published since the mid-19 $9^{\text {th }}$ century (Регель, 1868; Атласъ плодовъ, 1903-1906).

In 1910, the first Horticulture School was founded at Bulduri manor. Later a Horticulture Trial Department of the Agriculture Institute was established in Priekuli. After the First World War, higher education in fruit growing was available at the University of Latvia.

In 1926, P. Gailītis started a plan for creating the Pūre Horticulture Experimental Station, which was founded in 1930 (Sudrabs, 1960). Its director P. Gailitis was the only researcher, and he was helped by student practicants. In 1934, a pomological orchard was established, along with evaluation of introduced and local fruit cultivars for their suitability to growing in Latvia. Investigations of growing technologies were started only in a few fields - soil management, tree training and need for irrigation. The Experimental Station had significant contribution to the development in small fruit growing. Studies were done in gooseberry propagation, and new cultivars resistant to mildew were introduced. Red currants were also propagated and later, following increased market demands, white currants. P. Gailitis carried out trials with a new propagation method of blackcurrants applying irrigation techniques learned in the Netherlands. For strawberry research the first support site was founded in Jürmala. Its first task was to control the spread of strawberry mites and nematodes in Jūrmala plantations by selecting and propagating healthy clones.

Research in cultivation of American cranberries was started in the end of 1930s with an experimental plantation in Abava river lowlands. Investigations with grapes were done both in glasshouses and open field and since 1938/39 also on Sabile Wine Hill.

The Baltic Bio-Entomology Station was founded in 1913, its director J. Bickis started investigations of pests on different hosts, including fruit crops (Бицкий, 1913). In 1922, the Station was reorganised into the Plant Protection Institute, in which studies of fruit cultivar tolerance to the most harmful pests and their control were carried out under the leadership of the mycologists J. Smarods and J. Vìksne. In the 1930s, J. Zirnitis studied the biology and control of strawberry nematodes, currant shoot borer and winter moth (Zirnitis, 1937). In the 1920s-1930s, researchers of the Institute published booklets summing up the results of the research of pests and their control methods (Smarods, 1936; Eglītis et al., 1937).

At the beginning of 1940s and during the Second World War, research continued. Damages caused to cultivars by two successive severe winters were evaluated. The least damaged appeared to be the local cultivars and some cultivars of I. V. Michurin. The area of experimental plantations in 1943 was about 20 ha. The widest research during this time was done with strawberries in field and glasshouse (Ozola and Dzelzkalēja, 2006).

\section{DEVELOPMENT OF RESEARCH DURING THE SO- VIET TIME (1945-1990)}

Deportations and emigration significantly reduced the number of experienced fruit growers in Latvia, yet fruit research continued both in Pūre and its support sites in Jūrmala, Sabile and Dviete. The Research Station was under the jurisdiction of the Institute of Biology, Latvian Academy of Sciences (Institute of Biology). At the beginning of the 1950s, research concerning problems of apple and plum pollination and use of growth regulators in fruit orchards was carried out at these locations by the Institute scientists A. Spolītis and E. Pētersons. 
Directly after the Second World War, the Kārḷi Pomological Orchard was founded, which later became Ogre Experimental Station where variety evaluation of fruit and berry crops had the main focus. Support sites were established in Koknese (A. Vīksne), Alūksne (V. Bleijers), Dobele (P. Upītis) and Iedzēni (A. Maizītis, R. Āboliṇ̌s and later R. Dumbravs) (Derilo et al., 1996).

Fruit and berry breeding. Breeding was carried out at experimental stations and their support sites (Skrīvele et al, 1991). Most cultivars of apples, pears and sweet cherries were developed at Iedzēni. Among these, the apple cultivars 'Forele' and 'Iedzēnu' are grown in commercial orchards to some extent. In pears the most popular cultivar is 'Suvenīrs'. The sweet cherry cultivars 'Aleksandrs', 'Iedzēnu Dzeltenais', 'Agris' and 'Balzāms' are propagated by Latvian nurseries. Research in apple breeding was carried out also by J. Taranova at the Institute of Biology. Of the cultivars created by P. Upitis, the most recognized cultivars have been the apple cultivar 'Ilga' and the pear cultivars 'Jumurda' and 'Paulina'. The amateur breeder J. Valters in Medze utilised Western European pear cultivars in his crosses, and obtained hybrids with attractive fruits but low winter-hardiness. Plum breeding was carried out by A. Spolitis at the Institute of Biology and by P. Upītis in Dobele. 'Lāse' and 'Minjona' are in the list of registered plum cultivars (Skrīvele et al,. 1999).

Blackcurrant breeding was started by A. Meḷehina, and crosses were carried out between cultivars of Ribes nigrum ssp. europaeum. Further on she continued breeding at the National Botanical Gardens (NBG) applying interspecific hybridisation. M. Eglite also joined this breeding programme (Strautina, et al. 1997). The cultivar 'Mara Eglite' was selected from these hybrids and is registered.

Strawberry breeding was done by A. Mel̦ehina, V. Dūks and P. Upītis. Only the cultivar of P. Upītis 'Jūnija Smaids' was included in the list of recommended cultivars for some time.

The gooseberry cultivars 'Koknese', 'Pārsla', 'Mazērkšķotā', 'Veldze', 'Pērse' were selected by the breeder A. Vìksne. Together with the cultivars bred by V. Šterns, namely 'Kuršu Dzintars' and 'Pārsla', they still form the basis of the gooseberry assortment in Latvia (Strautina and Lacis, 2000). The thornless gooseberry cultivar 'Rita' was selected from hybrid material of A. Vīksne at the Latvia State Institute of Fruit-Growing and registered in 2012. His red currant cultivar 'Vīksnes Sarkanās' is included in the recommended Latvian variety assortment for commercial growing (Skrīvele et al., 1991, 1995).

Breeding of Japanese quince (Chaenomeles japonica) for fruit purposes was started in the 1950s in Pūre by A. Tīcs (Tîcs, 1992). Since the 1990s, it was continued in Dobele by S. Ruisa. A joint research project on C. japonica in collaboration with Swedish, Finnish, Lithuanian, French and
Spanish scientists was carried out during 1999-2001 (Rumpunen et al., 1996).

Breeding of apricot and peach was started at the Botanical Gardens of the University of Latvia by V. Vārna and continued by I. Stražinska. This programme has resulted in two apricot and two peach cultivars registered in Latvia that are grown in home gardens (Ruisa and Kaufmane, 2008).

Good results were also achieved in grape breeding by P. Sukatnieks in Dviete. Six of his cultivars are registered in Latvia and Sweden (Dobelis, 1999).

Breeding of Vaccinium spp. was started at NBG by A. Ripa, resulting in several promising hybrids (Ripa, 1996). In 2010, two cultivars were registered from this material.

Variety testing. After the Second World War, a group of researchers carried out expeditions throughout Latvia and found that the cultivars of local origin had survived the severe winters well. They evaluated and selected also accessions of different fruit crops, the best of which were propagated as landraces. Several of these are still worthy of growing, like the apple cultivars 'Krapes Cukurinš', 'Cēsu Sīpoliņš', 'Rīgas Rožābele' and 'Jelgavas Vasaras', as well as the pear cultivar 'Talsu Skaistule' (Sudrabs, 1950; Spolītis et al., 1955).

Evaluation of cultivars was carried out in new plantings where clones of local varieties and landraces as well as new cultivars of Soviet breeding were compared. The collections at Pūre and Ogre experimental stations were continuously extended and renewed. Through the work at the All-Union Institute, also cultivars bred in Western Europe and Northern America were introduced. As a result of this research the cultivars which form the present commercial orchards were selected, namely the apple cultivars 'Auksis', 'Antey', 'Belorusskoe Malinovoe', 'Konfetnoe', 'Kovalenkovskoe', 'Orlik', 'Rubin' (Kazakhstan cv.), Saltanat', 'Spartan', 'Tiina', 'Zarya Alatau' etc. and the pear cultivar 'Belorusskaya Pozdnaya' (Скривеле, 1983; 1988; Skrīvele, 1998;). Large plum collections were established and evaluated in Pūre and Ogre in this period (Jekovičs, 1972), and testing of berry crops was done at both Stations (Dūks, 1981; Derilo et al., 1996).

In the end of the 1980s, evaluation of fruit and berry cultivars was started at Dobele Laboratory of Pomology (Skrīvele et al., 1995).

The laboratories at Pūre evaluated the biochemical content of fruits and berries, introducing methods for analysis of the enzymes ascorbinoxidase, polyphelonoxidase and peroxidase. The suitability of cultivars for jams, purees, compotes, juices, wines and later also freezing was tested (Brencsons, 1966; Gūtmanis, 1961). Biochemical studies were performed also at Dobele (Ruisa, 1991). 
Research of orchard management. In 1947, an apple orchard on rootstocks M.1, M.2, M.4 and M.9 was planted at the Pūre Experimental Station. Wider studies were started in 1969 when large trials were established with rootstocks from East Malling and Michurinsk. Further studies showed that Russian rootstocks performed significantly better than East Malling rootstocks in Latvia. In 1971, a promising rootstock Pure1 was selected from seedlings of B.9 (Bite, 1978), which at present is propagated by commercial nurseries (Lepsis, 2006).

In 1987-1989, complex trials were established at Pūre to study the compatibility of promising apple cultivars with different rootstocks, as well as tree training methods for variety-rootstock combinations. In 1987, the first modern orchard on the dwarf rootstock B 9 was established.

Studies on bush fruit fertilisation and nutrient content in soil and leaves were carried out by A. Gross at Pūre and several state farms (Гросc, 1974). The research showed that each crop in dependence of other factors has its own nutrient optimum, and the yield responds negatively both to low and high nutrient content in the soil (Gross and Dimza, 1994). The research showed no difference in the source of nutrient supply - mineral or organic, while effect of irrigation was significant only in years with less precipitation (Димза et al., 1974).

Extended studies were performed also on the effects of microelements and growth regulators on fruit cropping and winter-hardiness (Dimza, 1965; 1958), as well as yield control with growth regulators (Скривеле и Димза, 1969; Skrīvele, 1965).

Trials with fertilisation of young apple-trees showed that even in soils with low content of organic matter and phosphorus and medium potassium content, trees responded positively to manure and organic fertilisers (Гросc, 1974). Various studies were carried out also on controlling yield bienniality by increasing fertiliser doses, by tree training and fruit thinning (Dimza et al., 1975).

Research on local cranberry fertilising and berry biochemistry was conducted at National Botanic Garden (Ripa, 1975).

At the Baltic branch of the All-Union Plant Protection Institute J. Zirnītis and L. Pētersons studied virus diseases of apple (Zirnitis, 1955). In the 1960s, a forecast system was developed for scab and other disease spore dispersal (Čakstin,a, 1962). In the1970s, Ilga Žerbele headed research on species composition and occurrence of the main fruit crop pathogens in field and storage, and their control (Эйхе, 1976). In the 1980s, monitoring of apple pests and diseases was carried out, a.o. studies on the distribution and control of pests and their economic importance thresholds (Priedītis, 1971). A complex plant protection system for orchards was developed (Žerbele et al., 1987). A simi- lar plant protection system for berry crops was developed in Pūre by I. Grosa.

The situation of fruit growing and its perspectives was reviewed in 1980s by V. Tumšs (Tumšs, 1986).

\section{DEVELOPMENT OF FRUIT SCIENCE IN THE TRAN- SITION PERIOD (1990-2000)}

The first years after regaining independence were very challenging for the fruit science in Latvia, mostly financially. Research stations that previously had been a complex enterprise, in which scientific trials were only a tiny part of the total activities and area, were now split up. Producers of fruits and berries from the Pūre Experimental Station seceded as "Pūres dārzi" Ltd. Processing units, greenhouses, stock and grain farming at the research unit also became separate commercial enterprises. Soon after the Experimental Station was privatised and reorganised as the Pūre Horticulture Research Centre (HRC). Similarly, the Ogre Experimental Station was separated from the large state organisation, but it did not survive further competition and was closed down. The land and buildings of the support site „Iedzēni” were returned to former owners or privatised, and all breeding material was handed over to Dobele and Pūre researchers. In 1991, the Baltic branch of All-Union Plant Protection Institute was reorganised into the Latvia State Plant Protection Centre, later renamed the State Plant Protection Research Centre (LSPPC).

In 1995, the Laboratory of Pomology of the Research Institute of Agriculture separated from a 6000 ha state farm, and became the Dobele Horticultural Plant Breeding Experimental station (Dobele HPBES). The first task of its researchers was to complete the evaluation of the material of the breeder P. Upitis. The genotypes selected as a result of evaluation were included as donors in five breeding programmes of the most important crops - apples, sweet cherries, Japanese quince, raspberries and blackcurrants. Extended collaboration with research institutions in Europe and the USA allowed significant broadening of the genetic base and access to more modern genotypes for variety testing. This work resulted in new recommendations of the best cultivars for commercial growing and selection of valuable breeding donors.

After private land property rights were restored, interest for intensive orchard establishment and growing technologies increased rapidly. In order to evaluate suitability of foreign experience of intensive fruit growing to local conditions, similar research had to be started in Latvia. Problems of the new commercial fruit growers had to be solved as soon as possible, and involvement and collaboration between scientists from several institutions was needed. For this aim a sub-programme, „Development and implementation of a system for competitive and profitable horticulture" was started in 1997 in the framework of the State 
Research Programme „Scientific background for development of agriculture in Latvia". In spite of insufficient funding, research was initiated in several directions (Skrīvele and Kaufmane, 1999).

The Experimental Fruit and Berry Processing Centre was established at the Dobele HPBES, in collaboration between HPBES and the Department of Food Technology of the Latvia University of Agriculture (LUA). This centre carries out research on suitability of fruit crop cultivars for freezing and new innovative products. During this period, a patent was taken for production of Japanese quince candied fruit.

In cooperation with the LUA Institute of Agricultural Polymers and Water Management, studies were started at Dobele concerning use of drip irrigation and mulching for apples on dwarfing rootstocks, raspberries, blackcurrants, strawberries, sweet cherries and plums.

In cooperation with $\mathrm{NBG}$, the suitability of grass mixes in orchard alleyways was studied, as well as adaptation of in vitro growing technologies for different Rosaceae fruit crops.

Pūre HRC carried out research of apple winter cultivar harvest time (Drudze, 2003). LSPPC carried out observations of orchard pest and disease development and optimal spraying times, as well as studies of apple scab infection forecasting for optimal fungicide use during primary infection (Eihe and Pušpure, 1995). Investigations continued on pheromone trap placement for prognosis of pest development in apple and berry plantations (Cinītis, 1995).

The Science Centre „Ulbroka” developed a system for mechanisation in fruit crop plantations together with technical specifications of recommended machinery.

At the Dobele HPBES nine trials were established with clonal rootstocks of different crops, to evaluate their suitability for Latvian conditions and compatibility with cultivars promising for commercial orchards. In the framework of a cooperation project with Iowa University, USA, trials were established with new rootstocks from the USA.

Investigations were completed in the trials established at Pūre in 1987-1989 with four clonal rootstocks, 24 apple cultivars and tree training system influence on productivity and fruit quality. These studies allowed discarding of unsuitable cultivar-rootstock combinations which radically reduce productivity of cultivars, like 'Iedzēnu', 'Korichnoe Novoe', 'Tiina' and 'Lobo' on B.490. Cultivar differences were established in the effect of distal shoot heading back on growth and productivity. The scale of trials allowed to performing economic research: to develop technological cards for intensive orchards, as well as calculate the profitability of such orchards and cultivars (Dimza et al., 1995; Skrīvele and Dimza, 1997; Skrīvele et al., 2000).

\section{LATVIAN FRUIT SCIENCE IN THE $21^{\text {st }}$ CENTURY}

After the turn of the millennium, more reorganisation of fruit science in Latvia took place in order to make the Latvian fruit and berry sector capable to meet future challenges. The leading research institution of fruit growing is now the Latvia State Institute of Fruit-Growing (LSIFG), which was founded in 2006 after re-organisation of Dobele HPBES.

There are five more institutions presently carrying out research in fruit-growing science in Latvia:

- Pūre Horticultural Research Centre (Pūre HRC);

- Latvian Plant Protection Research Centre (LPPRC);

- Institute of Agrobiotechology, Latvia University of Agriculture (IA LUA);

- Faculty of Food Technology, Latvia University of Agriculture (FFT LUA);

- Laboratory of Plant Mineral Nutrition, LU Institute of Biology (LU IB).

Research is carried out in the following directions:

- breeding and cultivar evaluation (LSIFG, Pūre HRC);

- genetics and molecular biology (LSIFG);

- plant pathology and entomology (LSIFG, LPPRC);

- orchard management (LSIFG, Pūre HRC, IA LUA, LU IB);

- experimental processing and storage_(LSIFG, FFT LUA).

Breeding and cultivar evaluation. The main task of the breeding programme is the development of market-competitive cultivars with high winter hardiness, productivity, fruit quality and technological properties, easy plant habit and suitability for integrated fruit production, including disease resistance. These criteria are also used to evaluate all new introduced cultivars. Since the breeding process of fruit crops is long and expensive, the crops for targeted hybridisation are selected together with the fruit growers. Farm trials are carried out for new cultivars and elite hybrids, to test their adaptability in different regions of Latvia. At present, breeding at LSIFG is performed for apples, sweet cherries, Japanese quince (Chaenomeles japonica), raspberries and blackcurrants, as well as small scale breeding of plums and pears, and at Pure HRC for apples, pears and strawberries.

A wide collection of fruit tree and berry genotypes (more than 3000) has been created to ensure material for breeding. Work on cultivar introduction is carried out for the above mentioned crops, as well as for sour cherries, apricots, red and white currants, gooseberries and grapes. Cultivars with proved value in field trials are planted for 
wider investigation of growing technologies and at farms, with the aim to select new cultivars suitable for commercial growing, and are used in breeding programmes.

Part of the breeding programme at LSIFG is carried out in the framework of international cooperative projects or programmes. The common breeding programme with Department of Horticulture at Balsgård, Swedish University of Agricultural Sciences, and Institute of Horticulture, Lithuanian Research Centre for Agriculture and Forestry (LIH) resulted in two cultivars of Japanese quince 'Rondo' and 'Darius', which have successfully passed DUS tests, and are prepared for registration in EU. This is the first time cultivars have been registered in this fruit crop (Ruisa, 1993; 1996; Krasnova et al., 2007). In cooperation with Swedish plum breeders, three productive, disease resistant plum cultivars with high quality fruits have been selected - 'Ance', 'Adelyn' and 'Sonora' (Kaufmane et al., 2012). Sweet cherry and pear breeding is performed in collaboration with the Norwegian Crop Research Institute (Feldmane and Ruisa, 2008). In 2010, a cooperation agreement in apple breeding with the Belgian company "Better3fruit" Ltd. was signed at LSIFG and Pūre HRC. Pūre HRC has a common pome fruit breeding programme with "Color" Ltd., South Africa. New opportunities for berry breeding were given by the EU co-funded project "RIBESCO - core collection of Northern European gene pool of Ribes" (information published in the Ribes database: http://www.ribes-rubus.gf.vu.lt/download.htm). In cooperation with Lithuanian, Swedish and Russian breeders, several promising blackcurrant hybrids have been selected (Strautina et al., 2012), and cultivar 'Karina' was registered.

Apple breeding at LSIFG was continued with the material transferred from „Iedzēni”. In recent years it has resulted in five cultivars resistant to scab (Ikase and Dumbravs, 2004a; Ikase and Lacis, 2013) and three columnar cultivars (Ikase and Dumbravs, 2004b; Ikase, 2007; Ikase and Lacis, 2013). Candidate cultivar 'Monta' was handed in for DUS testing in 2012. Promising apple and pear cultivars from „Iedzēni” material have also been selected at Pūre HRC (Drudze, 2000; 2004). At present, the apple crossing programme is continuing at LSIFG.

As a result of sweet cherry breeding, the cultivar 'Paula' was selected and registered in 2011 (Ruisa, 2011; Ruisa and Krasnova, 2013).

In the raspberry breeding programme, seven cultivars have been selected and registered, of which the most important is 'Ina' (Strautina et al., 2012).

The most important result of the breeding work at Pūre HRC has been a new strawberry cultivar 'Suitene', which was registered in 2010 .
The grape breeder G. Vēsmin̄š in Cīrava, Liepāja district obtained disease resistant and hardy grape selections of Vitis vinifera and other species. New named cultivars include 'Dovga', 'Liepājas Dzintars', 'Ciravas Agra', all extremely early ripening white wine varieties for the Baltic climate (Vēsmiņš, 2012).

For many years, variety testing of introduced blueberry and cranberry cultivars has been carried out at the Department of Horticulture of LUA. Several cultivars adapted to the Latvian climate have been selected as a result of this work (Abolins et al., 2009).

The cultivars and hybrids of different crops bred at LSIFG and Pūre HRC are tested in collaborating scientific institutions of twelve European countries (Czech Republic, Estonia, Finland, Germany, Lithuania, Netherlands, Norway, Poland, Romania, Russia, Slovakia and Belarus) as well as in a number of private companies: e.g. Bioessensa International Ltd (Sweden), GEVO Ltd (Germany), Žagares Sodai Ltd (Lithuania), Meiosis Ltd (Great Britain) and IFO (France).

As the establishment of a new system for registration of fruit crop cultivars after regaining of independence took time, the first official registration of new cultivars started after the year 2000. At present, 71 fruit cultivars of Latvian origin (29 apple, eight pear, five sweet cherry, four plum, four apricot, two pear, six raspberry, two blackcurrant, six grape, one strawberry, one lingonberry, one blueberry, one gooseberry and one Japanese quince) are registered in Latvia. Most of these are grown in home gardens. Potentially promising for commercial growing are the new apple cultivars 'Agra', 'Roberts', 'Gita', 'Dace', 'Edite', 'Eksotika', apple rootstock 'Pure1', pears 'Suvenirs', plums 'Lāse', 'Minjona', sweet cherries 'Aija', 'Indra', raspberries 'Ina', 'Lina', gooseberry 'Rita', blackcurrants 'Mara Eglite' and 'Karina', Japanese quince 'Rasa', and grapes 'Zilga', 'Supaga', 'Sukribe'.

Latvia is the main market for the Latvian cultivars, but six grape cultivars are registered in Sweden and two apple cultivars in Belgium (LSIFG). One apple rootstock and two apple cultivars are under the procedure of EU registration at present (Pūre HRC). A total of 156 fruit tree and berry bush cultivar propagation licenses have been sold to Latvian, Lithuanian and Swedish nurseries during the last five years.

Genetics and molecular biology. The research area in fruit crop genetics and molecular biology can be divided into two main activities which are mutually connected: (1) research on fruit crop genetics, development and application of molecular markers and (2) development of advanced fruit crop breeding methods. Although the first activities in the implementation of molecular genetics in fruit crop research started in 1996, comprehensive investigations at LSIFG started in 2005 by the establishment of 
Laboratory of Molecular Biology, which turned into the Unit of Genetics and Molecular Biology in 2008.

The main activities in fruit crop genetics have been linked to the evaluation and characterisation of plant genetic resources (PGR). The methods for phenotypic and genetic characterisation have been developed or/and adopted (apple, pear, cherry, plums, berry crops, sea buckthorn). Introduction of molecular markers has been important in these activities. In this context the whole germplasm of cherries and berry crops (black, red, white currants, gooseberries) has been genotyped along with the most important part of the apple germplasm (Lacis et al., 2009; 2011; Lacis, 2010; Antonius et al., 2012). The acquired information has been utilised for more accurate definition of pedigree, analysis of genetic diversity in the collections, detection of valuable gene sources for breeding and research on crop cultivation history in the area. Characterisation data has been included in an on-line tree crop data base, developed in cooperation with information technology experts. An important research area has been self-incompatibility genetics in Prunus. $S$-gene allele genotyping has been carried out for sweet cherries along with further inheritance and population analysis (Lacis et al., 2008). Research of plum self-incompatibility has started to apply molecular and cytoembryological approaches. Due to climate changes the breeding for resistant cultivars is becoming increasingly important. Therefore, research on resistance to apple and pear scab has been started utilising molecular genetics, searching for new resistance sources and for clarifying resistance inheritance mechanisms. A new fungal disease caused by Gnomonia fragariae has become severe in strawberry growing; hence research of possible resistance mechanisms and resistance sources has been started.

Fruit crop characterisation and application of different gene markers has been carried out in cooperation with Genetic Resources Centre of Latvia at the forest research institute "Silava" (Lacis et al., 2011). The collaboration with Prof. A. F. Iezzoni Laboratory at the Department of Horticulture, Michigan State University, USA and Swedish University of Agricultural Sciences had significant impact to the implementation of molecular approaches in fruit crop genetic research and breeding in Latvia. This collaboration resulted in comprehensive characterisation of cherry plant genetic resources in Latvia, as well as implementation of MAS (Marker Assisted Selection) in cherry breeding (self-compatibility Sf gene) (Lacis et al., 2008; 2009; Lacis, 2010).

Several molecular markers have been introduced into the routine breeding process: e.g. markers for apple scab resistance gene Rvi 6 ( Vf), sweet cherry self-compatibility allele $S 4$ ' and markers for detection of sweet cherry compatibility groups. The work is progressing for other genes important in breeding (additional apple scab resistance gene markers, markers for resistance to Gnomonia fragariae in strawberries).
Plant pathology and entomology. At present two institutions are involved in research on plant pathology and entomology aspects of fruit crops in the country - LSIFG and LPPRC.

In LSIFG research activities in plant pathology and entomology started in 2006 when the Laboratory of Plant Pathology was established. Research is carried out in mycology, virology, bacteriology and entomology in order to establish a scientific basis for sustainable and effective plant protection systems in the orchards based on correct diagnosis of pathogens and pests, knowledge of pathogen and pest occurrence, population structure and dynamics, genetic diversity as well as interaction mechanisms with hosts. Also, great efforts are made to establish nuclear stock collections for the main fruit species in order to achieve a starting point for a certified plant material system, which currently is not available in the country.

Surveys on occurrence of insect pests and diseases caused by viruses, bacteria and fungi in the main fruit species are carried out in collaboration between LSIFG and LPPRC in order to detect widespread pests and diseases and to determine the most serious threats for orchard crop loss in Latvia. Several new fungal and bacterial pathogens and insect pests have been identified in the country, e.g. the first established population of Gelechia hippophaella on seabuckthorn (Stalažs and Savenkovs, 2011). Several emerging disorders were identified, e.g. strawberry root rot and petiole blight caused by Gnomonia fragariae Kleb. (Morocko et al., 2006). Since strawberry root rot and petiole blight was discovered, research has been going on concerning characterisation of the infection process of the host, G. fragariae virulence and strawberry cultivar susceptibility, genetic diversity and phylogeny of G. fragariae and evaluation of effects of cultural practices on disease severity (Moročko and Fatehi, 2007; Moročko-Bičevska et al., 2011; Moročko-Bičevska and Fatehi, 2011).

Studies on the occurrence and genetic diversity have been focused on the most important viruses on Malus and Pyrus, Plum Pox virus and small fruit viruses (Pūpola et al., 2009; Pūpola et al., 2010; Glasa et al., 2011; Pūpola et al., 2011). Research has been started on identification of which species of Ribes are infested by particular species of Cecidophyopsis mites occurring in Latvia, along with determination of their role in BRV transmission and inconsistency of Ribes resistance to big bud disorder (Stalažs, 2011). Studies on other important pathogens have been started and include identification of pathovars and races of Pseudomonas syringae occurring on fruit crops, determination of Venturia inaequalis races occurring in Latvia and characterisation of $V$. inaequalis and $V$. pyrina population diversity. Research activities concerning determination of $V$. inaequalis races is a part of the global network (http://www.vinquest.ch/index.html) for monitoring of Venturia inaequalis pathotypes, which aims to introduce 
international monitoring for changes in $V$. inaequalis virulence in different populations to provide knowledge for breeding of durable resistance.

A range of pest and disease problems in orchards has been studied by the Latvian Plant Protection Research Centre. In this context, studies concerning biology, epidemiology and control methods of apple scab Venturia inaequalis have been carried out (Eihe et al., 2009). Another study direction is features of the life cycle of pear scab $V$. pyrina, concerning the fungus behaviour in winter. Fruit rots of crops from the genus Vaccinium have been investigated: identification of species of the pathogens involved and describing their life cycles. Vilka et al. (2009a; 2009b) published the first descriptions in Latvia of the causal agents of blueberry fruit rot Colletotrichum acutatum, necrosis of the cranberry vertical shoots and cranberry viscid rot Phomopsis vaccinii. Control methods of blueberry fruit rot were evaluated in another study by Volkova et al. (2012).

Studies have been performed to adopt innovative IT-based technologies in forecast and use of calculation methods for harmonising recommendations for apple scab Venturia inaequalis and for codling moth Cydia pomonella under the agro-climatic conditions of Latvia. These models have been developed in cooperation with Bio Fruit Advies Ltd, The Netherlands (Rancane et al., 2008).

Due to the increasing economic importance of the American commercial cranberry in horticulture, a diversity of pests species in the plantations was studied (Эйхе и др., 2005). The biology of the cranberry tipworm Dasineura vaccinii (Smith) was described for the first time in Latvia (Apenite, 2010).

Another study was on detection and control methods of cherry fruit fly Rhagoletis cerasi (Ozolina-Pole and Apenite, 2010).

Orchard management. This part of research includes testing of pome and stone fruit rootstocks, rootstockcultivar combinations for different growing conditions in Latvia and compatibility of rootstocks bred in Russia, Europe, USA and other countries. The apple rootstocks B.9, B.396, M.26, MM 106, M.26 EMLA, B.118 have been recommended for orchards in Latvia (Skrivele et al., 2011; Rubauskis et al., 2011). More extensive testing should be carried out with the promising apple rootstocks Mark, Ottawa 3 and G.30. Pear rootstocks originating from Cydonia oblonga have been found to be unsuitable for Latvian conditions, while Pyrodwarf may be more promising (Prokopova and Blukmanis, 2008; Lepsis and Drudze, 2011). In plums, the rootstock PU-20651 (Prunus cerasifera $x$ ussuriensis) was obtained and tested at LSIFG, and has proven to be promising (Kaufmane et al., 2007). Rootstocks recommended for cherries are at present seedlings of Prunus mahaleb. For this reason, investigations on other rootstock types that are promising in Europe have started, along with studies of the suitability of vitro propagated local sour cherry 'Latvijas Zemais' as a rootstock. Research on the production characteristics and somaclonal variability of sour cherries propagated by meristems has also begun.

Pūre HRC takes part in the project "Baltic rootstock studies", in collaboration with the Polli Horticultural Research Centre (Estonia), Lithuanian Institute of Horticulture (LIH), Brest Regional Agricultural Experimental Station (Belarus) and Research Institute of Horticulture (Poland). The main aim of this project is to evaluate 15 apple, 16 plum and five pear rootstocks under Baltic growing conditions. Several rootstocks of Polish origin are included in the trials, and the rootstocks P62 and P67 have shown good winter-hardiness (Kviklys et al., 2006). Good results were obtained for the plum rootstocks Brompton and Wangenheim (Декена et al., 2011).

At the LSIFG, studies were carried out to estimate effects of fertigation and sawdust mulch on the root system distribution of rootstock B9, along with determination of productivity and mineral nutrient removal of scion cultivars grafted on it (Surikova et al., 2011). Trials with different mulching methods are continuing in apple, sour cherry and blackcurrant plantings, as well as on the effect of mulch on soil activity in strawberry plantations. The use of soil covering with Agryl was found to be promising for Japanese quince growing (Ruisa and Rubauskis, 2004); therefore, a broader trial on the soil surface covers and new varieties has been established.

New investigations have started in the field of tree training and support systems, rootstock-cultivar combinations and planting distances of new and some traditional apple cultivars, as well as on the influence of planting material quality (standard or virus-tested). Under the same topic, plum cultivar, rootstock and tree training investigations have started at LSFIG in cooperation with LIH. At LUA investigations of cranberry pollination processes and blueberry plant training methods are carried out.

In cooperation with LPPRC, Pūre HRC and the Faculty of Computing, University of Latvia, research is carried out that involves advanced information technologies on data transfer to provide solution for microclimate monitoring. Investigations of risk-reducing technologies in sweet cherry, raspberry (including primocane) and strawberry production were started to test the suitability of these technologies for Latvian climatic conditions, local cultivars, rootstocks and growing systems.

In cooperation with Pūre HRC, investigations are carried out on the possibilities to prolong the strawberry season, using different top covers and mulches (Laugale et al., 2012). Studies have started about the possibilities of using high tunnels for strawberry, floricane and primocane rasp- 
berry growing (Kalniņa, 2011; Kalniņa and Strautiņa, 2012).

Studies of mineral nutrition regimes and methods of nutrient supply to plants are going on with apples, sour cherries (Feldmane, 2011), as well as cranberries (Osvalde and Karlsons, 2010) and blueberries (Osvalde et al., 2009), to reduce soil and water pollution risks.

Investigations are continuing concerning the fruit quality of promising apple cultivars in relation to rootstock type and method of mineral nutrient supply, as well as the degree and time of fruit thinning.

Experimental processing and storage. Since 2005, LSIFG includes units of experimental processing laboratory, laboratory of biochemistry and laboratory of fruit storage, which carry out research in close linkage with breeding and variety testing.

Fruit and berry processing is carried out mainly in the field of applied research, with an emphasis on healthy, functionally active product development for food and dietary supplements and market diversification. Testing of the suitability of cultivars for various ways of processing and development of new products include analyses of the biochemical content of raw material and their processed products. Physical and chemical indicators are evaluated for traditional (apple, pear, plum, cherry, raspberry, currants, gooseberry, strawberry) and untraditional (sea-buckthorn, American cranberry, blueberry) fruit crops and their processed products. In the context of new product development, one of the research directions is related to the analysis of anthocyanins, tocopherol, phloridzin and their compounds, as well as fruit fibre in raw material. Research has started on crab apple and blackcurrant pomace chemical composition for their use in production of healthy foods and dietary supplements. The data of chemical composition are included in internationally accessible databases. Special attention is paid to research on Japanese quince fruit and development of new processed products for commercial uses (Seglina et al., 2009a). Sea buckthorn cultivar characterisation and application for different food and feed products has been performed in cooperation with LUA, LIH, and Lithuanian Research Centre for Agriculture and Forestry (Seglina et al., 2009b; Ositis et al., 2010). In collaboration with a private enterprise a new study of sea buckthorn leaves for the development of pharmaceutical product has been initiated.

In collaboration between LSIFG and LUA, Faculty of Food Technology, research on the use of different packaging materials (including biodegradable) in packaging of fruit/berry processed products is carried out (Seglina et al., 2012). Work on fresh-cut product development using local raw materials has started. It is conducted in several stages, starting with suitable raw materials to development of technologies, choice of packaging materials, as well as economic evaluation that will be useful for processing companies (Krasnova et al., 2012).

Investigations on applying different methods for the determination of fruit harvest maturity for fruit storage in cooling chambers are carried out in collaboration between LSIFG and Pūre HRC. A sufficient data set has been elaborated for maturity and harvest parameters for local cultivars. Research on fruit and berry storage is carried out in conditions used in commercial production: standard cooling chambers with controlled temperature and controlled atmosphere (CA) chambers with variable $\mathrm{CO}_{2}$ and $\mathrm{O}_{2}$ gas regimes (Juhnevica et al., 2009). Based on international experiences, a new research direction was launched for extension of fruit shelf life using the growth regulator 1-methylcyclopropen (1-MCP). LSIFG and Pūre HRC have collaborated in a study on the storage of different apple cultivars in the same room using 1-MCP. This technique saves energy in comparison with $\mathrm{CA}$ chambers.

The contribution of science in the development of fruit growing industry. In the 1990s, a new system for commercial fruit growing was introduced in Latvia, which involved a transition to semi-dwarf and dwarf rootstocks and intensive orchard management. LSIFG has been the leading initiator, involving other scientific institutions in research programmes, introducing new technologies, fruit crops and cultivars, and transferring the latest knowledge and technologies in farms. The results are spread to farmers through various activities: (1) training seminars in various regions of Latvia and farms, (2) field days at the Institute, (3) advisory service, (4) lectures, (5) educational materials (booklets, DVD, books) and articles in the most popular industry-related magazines, and (6) participation and organization of exhibitions.

The activities of scientific institutions partly compensate the shortage of extension service in fruit-growing of Latvia. The Latvian-Lithuanian cross-border cooperation programmes allowed to establish a Technology Transfer Centre (TTC) for fruit growing in collaboration between LSIFG and LIH. A web-site has been constructed and is regularly updated, providing information about TTC activities and the created information materials, and answering questions both from growers and consumers (www.fruittechcentre.eu).

LSIFG has established successful cooperation with the Latvian fruit and berry processing companies. There are different forms of cooperation: raw material testing, development of new products and recipes, and implementation in production. All LSIFG patented technologies are used in production. Currently more than twenty products developed at LSIFG are available for purchase in stores.

One of the most successful cooperation initiatives with the fruit growing sector is the close collaboration with the Latvian Fruit Growers Association. LSIFG was the initiator of its establishment in 1998. Institute scientists have been board members from the founding of the organisation, and therefore, all key issues in the fruit growing sector (includ- 
ing development of legislation, subsidies for orchard establishment, integrated fruit and berry production system in Latvia, etc.) are resolved on the basis of the Institute scientists' research results as well as the best experience in Latvia and abroad.

The area of commercial fruit growing in Latvia is expanding due to the work of scientific institutions in fruit growing. Scientists contribute directly and indirectly to the development of small and medium-sized enterprises in Latvia, enabling them to produce fruits (fresh and processed), both for Latvian consumers, and for export.

\section{REFERENCES}

Abolins, M., Liepniece, M., Sterne, D. (2009). Vaccinium spp. production patterns and winter hardiness in Latvia. Acta Hort., 810, 205-210.

Antonius, K., Karhu, S., Kaldmäe, H., Lacis, G., Rugenius, R., Baniulis, D., Sasnauskas, A., Schulte, E., Kuras, A., Korbin, M., Gunnarsson, A., Werlemark, G., Ryliskis, D., Todam-Andersen, T., Kokk, L., Järve, K. (2012). Development of the Northern European Ribes core collection based on a microsatellite (SSR) marker diversity analysis. Plant Gen. Res. Char. Utiliz., 10 (1), 70-73.

Apenīte, I. (2010). Dzērveņu dzinumu pangodina Dasineura vaccinii (Smith) biolog̣ija, ekologiija un ekonomiskā nozīme Latvijā [Biology, Ecology and Economic Significance of the Cranberry Tipworm Dasineura vaccinii (Smith) in Latvia]. Doctoral Thesis, Latvia, Jelgava. 100 pp.

Bite, A. (1978). Ābeḷu klonu potcelmu pārbaudes rezultāti kokaudzētavā [The results of comparison of apple rootstocks in nursery]. Tautsaimniecībā derīgo augu selekcija un bioḳimija (16.-24. lpp.). Rìga: Zinātne (in Latvian).

Brencsons, A. (1966). Augḷu un ogu škirṇu piemērotība rūpnieciskai pārstrādei [The suitability of fruit and berry cultivars for industrial processing]. Grām.: Auglu ražas katru gadu (233.-251. lpp). Rīga: LVI (in Latvian).

Čakstina, T. (1962). Auglu dārzu kaitēkḷi un slimības [Pests and Diseases of Fruit Orchard]. Rīga: LVI. 208 lpp. (in Latvian).

Cinītis, R. (1995). Kukaiṇu dzimumferomonu pielietošana ābeḷu kaitēkḷu uzskaitē un prognozēšanā. [Use of insect sexpheromones for counting and forecasting of apple pests]. In: Proceedings of Scientific Practical Conference, 9-10 February 1995, Latvia, Jelgava, Latvia University of Agriculture. LLU Raksti, 14, 9-10 (in Latvian)

Daija, P. (2008). Johans Hermanis Cigra. Latvijas Universitātes Raksti, 738 , 170-180 (in Latvian)

Derilo, B., Jekovics, V., Antrops, J. (1996). Pētījumi dārzkopībā [Investigations in horticulture]. Latvijas Valsts Zemkopïbas ZPI „Agra” 50 darba gadi (137.-153. lpp). Skrīveri (in Latvian).

Dimza, I., Gross, A., Skrīvele, M., Ūdris, J. (1975). Agrotehnikas pasākumu komplekss ābeḷu ražošanas periodiskuma novēršanai [Complex of agro-technological actions for preventing of bienniality of apple yielding]. Grām.: Tautsaimniecībā derīgo augu agrotehnika (56.-64. lpp.). Rīga: Zinātne (in Latvian).

Dimza, I. (1958). Mikroelementi auglkopībā [Microelements in Fruit-growing]. Rīga: LVI. 54 lpp. (in Latvian).

Dimza, I., Dimza, V. (1965). Augšanas regulatori auglkopībā [Growth Regulators in Fruit-growing]. Rīga: Liesma. 98 lpp. (in Latvian).

Dimza, I., Skrīvele, M., Jansone-Henkuzene, I. (1995). The effect of pruning treatments on different apple cultivars. In: Tasks and Perspectives of Orchard Plant Breeding (pp. 124-130). Babtai, Lithuania: Lithuanian Institute of Horticulture.

Dobelis, G. (1999). Iestādi savu vīnkoku [Plant Your Grape-tree]. Rīga: Dārzs un Drava. 72 lpp. (in Latvian).
Drudze, I. (2000). Studies of perspective apple and pear hybrids of breeding station „Iedzeni” in Latvia. Acta Hort., 538, 729-734.

Drudze, I. (2003). Investigations of harvest maturity and suitability for storage of some apple cultivars in Latvia, Acta Hort., 599, 631-635.

Drudze, I. (2004). New apple and pear selections from hybrid material of „Iedzeni” in Latvia. Acta Hort., 663, 895-898.

Dūks, V. (1981) Avenes [Raspberries]. Rīga: Avots. 135 lpp. (in Latvian).

Eglītis, H., Eglītis, M., Ozols, E., Kirulis, A., Smarods, J., Starcs, K., Zirnītis, J. (1937). Kultūraugu kaitēkļu, slimību un nezāḷ apkarošana [Control of Cultivated Crop Pests, Diseases and Weeds]. Rīga. 207 lpp. (in Latvian).

Eihe, M., Pušpure, L. (1995). Ābeḷu kraupja ierosinātāja Venturia inaequalis (Cooke) Wint. izplatības prognozes nozīme slimības ierobežošanā [Importance of spread prognosis of Venturia inaequalis (Cooke) Wint. to restriction of diseases]. In: Proceedings of Scientific Practical Conference, 9-10 February 1995 (15.-16. 1pp.). Latvia, Jelgava: Latvia University of Agriculture (in Latvian).

Eihe, M., Rancane, R., Vilka, L. (2009). Different fungicide combinations against apple scab helping to avoid fungus resistance. Sodininkyste ir Daržininkystè, 28 (3), 57-67.

Feldmane, D. (2011). Response of young sour cherry trees to woodchip mulch and drip irrigation. In: Proceedings of 8th international scientific and practical conference ,Environment. Technology. Resources”, 20-22 June 2011 (pp. 252-260). Latvia, Rēzekne: Rezekne Higher Education Institution.

Feldmane, D., Ruisa, S. (2008). The estimation of some sweet cherry (Prunus avium L.) hybrids at the Latvia State Institute of Fruit Growing. In: Proceedings of International Scientific Conference „S Sustainable Fruit Growing: Form Plant to Product”, 28-31 May 2008 (pp. 38-43). Latvia, Jūrmala - Dobele: Latvia State Institute of Fruit-Growing.

Glasa, M., Malinowski, T., Predajna, L., Pūpola, N., Dekena, Dz., Michalczuk, L., Candresse, T. (2011). Sequence variability and recombination analysis of the $\mathrm{W}$ strain of Plum pox virus. Phytopathology, 101, 980-985.

Grāvīte, I., Kaufmane, E. (2011). Stability of some quality characteristics of new plum cultivars in Latvia. Sodininkystè ir Daržininkystè, 30 (2), 23-34.

Gross, A., Dimza, I. (1994). Auglu dārzu mēslošana un augsnes strādāšana [Fertilizing of Orchards and Soil Management]. Rīga: Agroinformācija. 22 1pp. (in Latvian).

Gūtmanis, K. (1961). Latvijas PSR augḷu bioḳimiskais sastāvs [Fruit Biochemical Content in Latvia] Rīga: LPSR ZA izdevniecība. 94 lpp. (in Latvian).

Ikase, L., Dumbravs, R. (2004a). Apple breeding for disease resistance in Latvia. Acta Hort., 663, 713-716.

Ikase, L., Dumbravs, R. (2004b). Breeding of columnar apple-trees in Latvia. Biologija, 2, 8-10.

Ikase, L. (2007). Evaluation of columnar apple hybrids on dwarfing rootstocks. Scientific Works of the Lithuanian Institute of Horticulture and Lithuanian University of Agriculture, 26 (3), 40-46.

Ikase, L., Lacis, G. (2013). Apple breeding and genetic resources in Latvia. Acta Hort., 976, 69-74.

Jekovičs, V. Plūmes [Plums]. (1972). Rīga: Liesma. 174 lpp. (in Latvian).

Juhnevica, K., Seglina, D., Krasnova, I., Skudra, G., Klava, D., Skudra, L. (2009). The evaluation of apple quality during storage at modified atmosphere. Chem. Technol., 3 (52), 30-37.

Kalniņa, I., Strautina, S. (2011). Zemeṇu audzēšana FVG tipa augstajos tunel̦os [Growing strawberries in FVG high tunnels]. Agrotops, 9 (60), 64-66 (in Latvian).

Kalnina, I. (2012). Augstie tuneḷi zemenu audzēšanai [High tunnels for strawberry growing]. Dārza Pasaules bibliotēka, 4 (19), 29-31 (in Latvian). 
Kārklinšs, J., Skrīvele, M., Kaufmane, E., Ikase, L. (2007). Plūmju škirnes [Plum Cultivars]. Rīga: Reneprint. 204 lpp. (in Latvian).

Kaufmane, E., Grāvīte, I., Trajkovski, V. (2012). Results of Latvian plum breeding programme. Acta Hort., 968, 55-60.

Kaufmane, E., Rubauskis, E., Skrivele, M. (2007). Influence of different rootstocks on the growth and yield of plum cultivars. Acta Hort., 734, 387-391.

Krasnova, I., Dukalska, L., Seglina, D., Juhnevica, K., Sne, E., Karklina, D. (2012). Effect of passive modified atmosphere in different packaging materials on fresh-cut mixed fruit salad quality during storage. World Acad. Sci. Eng. Technol., 67, 1095-1104.

Krasnova, I., Ruisa, S., Seglina, D. (2007). Investigations of the biochemical composition of Chaenomeles japonica fruits. Chem. Technol., 4 (46), $16-20$

Kviklys, D., Kvikliene, N., Bite, A., Lepsis, J., Lukut, T., Haak, E. (2006). Baltic fruit rootstock studies: Evaluation of 12 rootstocks for apple cultivar ‘Auksis'. Sodininkystè ir Daržininkystè, 25 (3), 334-341.

Lacis, G. (2010). Characterisation of the Latvian and Swedish Sweet and Sour Cherry Genetic Resources. Acta Universitatis Agriculturae Sueciae, Doctoral Thesis, No. 2010:89, Sweden.

Lacis, G., Kaufmane, E., Rashal, I., Trajkovski, V., Iezzoni A. F. (2008). Identification of self-incompatibility $(S)$ alleles in Latvian and Swedish sweet cherry genetic resources collections by PCR based typing. Euphytica, 160, 155-163.

Lacis, G., Kota, I., Ikase, L., Rungis, D. (2011). Molecular characterization of the Latvian apple (Malus) genetic resource collection based on SSR markers and scab resistance gene $V f$ analysis. Plant Gen. Res. Char. Utiliz., 9 (2), 189-192

Lacis, G., Rashal, I., Ruisa, S., Trajkovski, V., Iezzoni, A. F. (2009). Assessment of genetic diversity of Latvian and Swedish sweet cherry (Prunus avium L.) genetic resources collections by using SSR (microsatellite) markers. Sci. Hort., 121, 451-457.

Laugale, V., Lepse, L., Strautina, S., Krasnova, I., Seglina, D. (2012). Effect of planting density and plastic soil mulch on strawberry plant development, yield and fruit quality. Acta Hort., 926, 517-525.

Laugale, V., Lepsis, J., Strautina, S. (2012). Extending strawberry production season in Latvia. Acta Hort., 926, 551-559.

Lepsis, J. (2006). Evaluation of apple rootstock Pure 1. Latvian J. Agron., 9, 75-79.

Lepsis, J., Drudze, I. (2011). Evaluation of seven pear rootstocks in Latvia. Acta Hort., 903, 457-461.

Morocko, I., Fatehi, J., Gerhardson, B. (2006). Gnomonia fragariae, a cause of strawberry root rot and petiole blight. Eur. J. Plant Pathol., 114, $235-244$.

Moročko, I., Fatehi, J. (2007). Molecular characterization of strawberry pathogen Gnomonia fragariae and its genetic relatedness to other Gnomonia species and members of Diaporthales. Mycol. Res., 111, 603-614.

Moročko-Bičevska, I., Fatehi, J. (2011). Infection and colonization of strawberry by Gnomonia fragariae strain expressing green fluorescent protein. Eur. J. Plant Pathol., 129, 567-577.

Moročko-Bičevska, I., Sokolova, O., Laugale, V. (2011), The effect of cultural practices on severity of strawberry root rot and petiole blight. $I O B C$-WPRS Bulletin (International Organization for Biological and Integrated Control of Noxious Animals and Plants, West Palearctic Regional Section), 70, 191-195.

Ositis, U., Seglina, D., Strikauska, S., Bula, S. (2010). Influence of sea buckthorn byproducts premix feeding on the mare and foal blood biochemical indices. In: Proceedings of the 1st Nordic Feed Science Conference, 22-23 June 2010 (pp. 137-142). Sweden: Uppsala.

Osvalde, A., Karlsons, A. (2010) Evaluation of the American cranberry nutrient status in Latvia during 2001-2007. Acta Hort., 868, 213-218.
Osvalde, A., Pormale, J., Karlsons, A., Nollendorfs, V. (2009) Mineral nutrition status of highbush blueberry, Vaccinium corumbosum L., in Latvia: Problems and tendencies. In: Proceedings of the XXXIII CIOSTA CIGR V conference. Technology and management to ensure sustainable agriculture, agro-systems, forestry and safety, 17-19th June 2009, Vol. 2 (pp. 1347-1351). Italy: Reggio Calabria.

Ozola, A., Dzelzkalēja, V. (2006). Dārzkopība un Pūre [Horticulture and Pūre]. Tukums: Pūres DIS, 144 lpp. (in Latvian).

Ozolina-Pole, L., Apenite, I. (2010). Suitable methods for determination of cherry fruit fly (Rhagoletis cerasi $\mathrm{L}$.) flying out in Latvia. The IOBC-WPRS Bulletin (in print).

Priedītis, A. (1971). Auglı koku un ogu krūmu kaitēkḷi [Pests of Fruit-trees and Berries]. Rìga: Liesma, 193 lpp. (in Latvian).

Prokopova, B., Blukmanis, M. (2008). The effect of rootstocks on growth and early bearing of pear cultivars in Latvia. Abstracts of international scientific conference ,S Sustainable Fruit Growing: Form Plant to Product”, May 28-31 2008 (p. 27). Jūrmala - Dobele, Latvia: LSIFG.

Pūpola, N., Kāle, A., Jundzis, M., Moročko-Bičevska, I. (2010). The occurrence of Ilarviruses in Latvian fruit orchards. Julius Kühn Archive, 427, 263-267.

Pūpola, N., Lepse, L., Kāle, A., Moročko-Bičevskka, I. (2009). Occurrence of RBDV in Latvia and virus elimination in vitro by chemotherapy. Hort. Vegetable Grow., 28, 165-171.

Pūpola, N., Moročko-Bičevska, I., Kāle, A., Zeltiņš, A. (2011). Occurrence and diversity of pome fruit viruses in apple and pear orchards in Latvia. $J$. Phytopathol., 159, 597-605.

Rancane, R., Eihe, M., Jankovska, L. (2008). Adaption of simulation model RIMpro for primary apple scab control in Latvia. Acta Hort., 803, 214-218.

Ripa, A. (1975). Mēslojuma ietekme uz dzērveņu Oxycccus quadripetalus Gilib. augšanu augsto sūnu, pārejas un zālu purvos [Influence of fertilizers on growth of cranberries Oxycccus quadripetalus Gilib. in moss, transitional and grass bogs]. Tautsaimniecībai derīgo augu agrotehnika (14.-36. lpp.). Rīga: Zinātne (in Latvian).

Ripa, A. (1996). Amerikas lielogu dzērvenes [American Large Fruited Cranberries]. Rīga: Latvijas zinību biedrība. 75 lpp. (in Latvian)

Rubauskis, E., Berlands, V., Skrivele, M., Ikase, L. (2011). Influence of fertigation and sawdust mulch on apple growth and yielding in Latvia. Acta Hort., 922, 311-318.

Rubauskis, E., Skrivele, M., Rezgale, Z., Ikase, L. (2011). Production of four apple cultivars on rootstock P 22. Sodininkystè ir Daržininkystè, 26 (3), 3-14.

Ruisa, S. (1991). Augḷu un ogu biokīmiskais sastāvs [Biochemical content of fruits and berries]. Informatīvais Bil̨etens "Agra", Nr. 1, 50.-55. 1pp. (in Latvian).

Ruisa, S., Kaufmane, E. (2008). Ķiršu, aprikožu un persiku šķirnes [Cultivars of cherries, apricots and peaches]. Dobele: LVAI, 212 lpp. (in Latvian).

Ruisa, S., Rubauskis, E. (2004). The effect of soil treatments on Chaenomeles japonica growth and productivity. Sodininkyste ir Daržininkystè, 23 (2), 224-231.

Ruisa, S. (1993) Japanese quince (Chaenomeles japonica (Thunb.) Lindl. ex Spach) as a fruit plant in Latvia. In: O Lepsza Jakość Produktów Ogrodniczych, 2 grudnia 1993 (pp. 68-71). Poland: Akademia Rolnicza w Krakowie.

Ruisa, S. (1996). Studies of Japanese quince (Chaenomeles japonica (Thunb. Lindl. ex Spach) in Latvia. SLU Balsgard, Department of Horticulture Plant Breeding, Report 1992-1994, pp. 194-195.

Ruisa, S. (2011). Saldais kirsis 'Paula' [Sweet Cherry 'Paula']. Praktiskais Latvietis, 3 (738), 16 (in Latvian).

Ruisa, S., Krasnova, I. (2012). Assessment of cherry cultivars and selections in Latvia. Acta Hort., 976, 161-166. 
Rumpunen, K., Kviklys, D., Kaufmane, E., Garkava, L. (1996). Breeding Chaenomeles - a new aromatic fruit crop. Acta Hort., 484, 211-216.

Seglina, D., Krasnova, I., Heidemane, G., Ruisa, S. (2009). Influence of drying technology on the quality of sweet dried Chaenomeles japonica during the storage. Latvian J. Agron., 12, 113-118.

Seglina, D., Ruisa, S., Krasnova, I., Viskelis, P., Lanauskas, J. (2009). Biochemical characterization of sea buckthorn (Hippophae rhamnoides L.) growing in Latvia. In: Proceedings of 3rd International Seabuckthorn Association Conference: "Promoting Sea Buckthorn Industry Worldwide Opportunities and Challenges" (pp. 159-168). Quebec: Laval University, Institute of Nutraceuticals and Functional Food.

Seglina, D., Strautina, S., Krasnova, I., Gailite, I., Dukalska, L., Suraka, V. (2012). The effect of packaging materials on the quality of dried candied black currants. Acta Hort., 946, 413-418.

Skrivele, M., Blukmanis, M., Ikase, L., Kaufmane, E., Ruisa, S., Strautina, S. (1995). Fruit breeding problems in Latvia: Current problems. Proc. Latvian Acad. Sci., Section B, No. 5/6, 109-113.

Skrīvele, M. (1965). Ābolu nobires novēršana [Preventing apple fall off]. Dārzs un Drava, 8, 1-2 (in Latvian).

Skrīvele, M. (1998). Ābeḷu škiirnes komercdārziem [Apple cultivars for commercial orchards]. Agrotops, 4-5, 32.-34., 28.-29. 1pp. (in Latvian).

Skrivele, M., Blukmanis, M., Dumbravs, R., Ikase, L., Kaufmane, E., Ruisa, S., Strautin,a, S. (1991). Aug̣,u koku un ogulāju selekcija Latvijā [Breeding of fruit-trees and berries in Latvia]. Augsne, selekcija, augkopība (36.-40. lpp). Rīga: Zinātne (in Latvian).

Skrivele, M., Dimza, I. (1997). The cropping of 15 apple cultivars on two rootstocks. In: Modern Orchards: Achievements and Tendencies (pp. 17-22). Babtai (Lithuania): Lithuanian Institute of Horticulture.

Skrivele, M., Ikase, L., Kaufmane, E., Ruisa, S., Blukmanis, M., Strautiņa, S., Laugale, V., Brūvelis, A., Ābolinšs, M., Rubauskis, E., Seglina, D., Eihe, M., Berlands, V., Epro, V., Drudze, I., Gertnere, D. (2000). Intensīvas auglkopības rokasgrāmata. [Handbook of Intensive Fruit-growing]. Dobele: Valsts Dobeles DSIS. 281 lpp. (in Latvian).

Skrīvele, M., Kaufmane, E. (1999). Auglkopība [Fruit Growing]. In: Latvijas lauksaimniecības zinātniskie pamati (4.36-4.38, 5.42-5.47, 11.33-11.34, 17.17-17.1). V. Strīkis (Ed.). Jelgava: Latvia University of Agriculture.

Skrivele, M., Kaufmane E., Ikase L. (1999). 'Lāse' and 'Minjona' — two new, promising Latvian plum varieties. In: Fruit Growing Today and Tomorrow (pp. 42-50). Dobele (Latvia)) Dobele HPBES.

Skrīvele, M., Kaufmane, E., Strautina, S., Ikase, L., Ruisa, S., Rubauskis, E., Blukmanis, M., Segliņa, D. (2008). Overview of fruit and berry growing in Latvia. Proceedings of International Scientific Conference „, Sustainable Fruit Growing: Form Plant to Product”, 28-31 May 2008 (pp. 5-14). Jūrmala - Dobele, Latvia.

Skrivele, M., Rubauskis, E., Ikase, L. (2011). Apple rootstocks in Latvian orchards: Situation and tendencies. Acta Hort., 903, 363-370.

Skrivele, M., Rubauskis, E., Strautina, S., Ruisa S., Ikase, L., Kaufmane, E., Berlands, V., Lāce, B., Grāvīte, I., Feldmane, D., Surikova, V., Apenīte, I., Rancāne, R., Vilka, L., Moročko-Bičevska, I., Stalažs, A., Kviklys, D., Nobertas, U. (2012). Cel̦vedis komercaugḷopībā [Guide in Commercial Fruit Growing]. Dobele: Latvijas Valsts Aug̣̣lkopības institūts. 188. lpp. (in Latvian).

Smarods, J. (1936). Slimību un kaitēkḷ u apkarošana ogu dārzos [Restriction of Diseases and Pests in Berry Orchards]. Cēsis / Rīga: Oskara Jēpes izdevniecība. 48 lpp. (in Latvian).

Spolītis, A., Romanovska, O., Kārkliṇ̌s, J. (1955). Latvijas PSR tautas selekcijas augḷ koku škirnes [Fruit-tree Landraces in Latvia]. Rīga: LPSR Zinātṇu Akadēmijas izdevniecība. 87 lpp. (in Latvian).

Stalažs, A. (2012). Diversity of currant (Ribes) species and cultivars infected by Cecidophyopsis mites in Latvia. Acta Hort., 946, 333-338.
Stalažs, A., Savenkovs, N. (2011). First report of an established population of Gelechia hippophaella (Schrank, 1802) (Lepidoptera: Gelechiidae) on seabuckthorn in Latvia. Latv. Entomol., 50, 9-12.

Sterne, D., Abolins, M. (2009). Evaluation of winter hardiness and productivity of five highbush blueberries cultivars in Latvia. In: Proceedings of Annual 15th International Scientific Conference "Research for Rural Development” (pp. 76-81). Jelgava: Latvia University of Agriculture.

Strautina, S., Kampuss, K. (2000). Influence of moisture conditions on the production and growth of black currant. Fruit Sci., 207, 168-172.

Strautina, S., Krasnova, I., Kalnina, I., Sasnauskas, A., Trajkovski, V., Tikhonova, O., (2012). Results of the common international breeding program for blackcurrants. Acta Hort., 926, 53-59.

Strautina, S., Lacis, G. (2000). Small fruit breeding in Latvia. Acta Hort., 538 (2), 469-472.

Strautina, S., Ruisa, S., Eglite, M. (1997). Evaluation of black currant cultivars and hybrids in collection. In: Proceedings of Scientific Conference, 13-14 February 1997 (pp. 107-109). Jelgava: Latvia University of Agriculture.

Sudrabs, J. (1950). Salcietīgās augḷu koku un ogulāju šķirnes [Winter-hardy Cultivars of Fruit-trees and Berries]. Rīga: LVI. 120 lpp. (in Latvian).

Sudrabs, J. (1960). Augḷkopība [Fruit Growing]. Rīga: LVI. 679 1pp. (in Latvian).

Surikova, V., Rubauskis, E., Kārklinš, A., Berlands, V., Skrivele, M. (2011). Apple-tree root development and distribution influenced by soil agrochemical properties, fertigation and mulching. Acta Hort., 922, 319-325.

Tīcs, A. (1992). Krūmcidonijas [Chaenomeles]. Rīga: Avots. 112. 1pp. (in Latvian).

Tumšs, V. (1986). Aug̣̣kkopības perspektīvā attīstība [Perspective development of fruit-growing]. Padomju Latvijas Lauksaimniecība, 7, 6-8 (in Latvian).

Vēsmiņš, G. (2010). Vīnogu kopšana vasarā [Care of grapes in summer]. Dārzs un Drava, 7/8, 39-41 (in Latvian).

Vēsmiņš, G., Vēsmiņa, L. (2012). Ieteicamās lauka vīnogu šķirnes [Recommended grape cultivars for field]. Agrotops, 5, 70-72 (in Latvian).

Vilka, L., Rancane, R., Eihe, M. (2009a). Fungal diseases of Vaccinium macrocarpon in Latvia. Latvia J. Agron., 12, 125-133.

Vilka, L., Rancane, R., Eihe, M. (2009b). Storage rots of Vaccinium macrocarpon, spread and development in Latvia. Latvia J. Agron., 12, 133-137.

Volkova, J., Bazenova, A., Rancane, R. (2012). Evaluation of treatments to control ripe rot caused by Colletotrichum acutatum Simmonds in blueberry. In: Proceedings of XII Meeting of IOBC-WPRS Working Group "Biological control of fungal and bacterial plant pathogens", Rheims, France, 24-27 June 2012 (in print).

Žerbele, I. (ed.). (1987). Augḷu koku un ogulāju kompleksā aizsardzības sistēma pret kaitēkliem, slimībām un nezālēm [Complex Plant Protection System of Fruit-trees and Berries against Pests, Diseases and Weeds]. Rīga: Zinātniski tehniskās informācijas pārvalde. 36 lpp. (in Latvian).

Zigra, J. H. (1803). Tas Āboḷu-dārznieks [The Apple Gardener]. Riga. 240 p. (in Latvian).

Zirnītis, J. (1937). Novērojumi par zemenāju nematode — Aphelenchus fragariae Rizema-Bos. 1935.-1936. g. [Observations on strawberry nematode - Aphelenchus fragariae Rizema-Bos. in 1935-1936]. Latvijas Augu aizsardzības institūta darbības pārskats par 1936.-1937. gadu (72.-74. lpp.). Jelgava (in Latvian).

Zirnītis, J., Pētersons, L. (1955). Latvijas PSR sastopamās ābeḷu vīrusu slimības. [Incidence of apple diseases caused by viruses in Latvia]. Latvijas Lauksaimniecības Akadēmijas Raksti, 4, 255-272 (in Latvian).

Атласъ плодовъ I-IV (1903-1906) [Fruit Atlas I-IV (1903-1906)]. Под. ред. А. С. Гребницкаго. СанктПетербургъ. 273 с. (in Russian). 
Бицкий И. Г. (1913). Отчет о деятельности Прибалтийской станции по борьбе с вредителями культурных растений при Рижском Центральном Сельскохозяйственном Обществе за 1913 год [Activity Report of Baltic Station about Restriction of Pests of Cultivated Plants at Roga Central Agricultural Society in 1913]. Венден: Тип. Я. Озолс. 28 c. (in Russian).

Гросс А. Л. (1974). Результаты удобрения молодых яблонь [Results of young apple fertilizing]. Научные основы интенсивного плодоводства (c. 79-90). Рига: Зинатне (in Russian).

Декена Д., Лепсис, Я., Алсиня, И. (2011). Оценка различных Европейских подвоев слив в климатических условиях Латвии [Estimation of different plum rootstocks of European origin in Latvia climatic conditions]. In: Materials of International Scientific Conference in Commemoration of $200^{\text {th }}$ Anniversary of Nikitsky Botanical Gardens: „Achievements and Perspectives of Development of Selection, Growing and Fruit Crops”, 24-27 October 2011 (c. 94-95). Yalta: NBG (in Russian).

Димза И., Гросс, А., Скривеле, М., Удрис, Ю. (1974). Результаты коплексного испытания минеральных и органических удобрений, полива, системы формирования крон и химического прореживания завязей в молодом саду [Results of complex investigation of mineral and organic fertilizers, irrigation, canopy training system and chemical thinning of fruitlets in a young orchard]. В сб.: Научные основы интенсивного плодовотства (с. 29-41). Рига: Зинатне, (in Russian).

Received 3 December 2012
Регель Э. (1868). Русская помология. Т. 1 [Russian Pomology. Vol. 1]. Издание Книгопродавца Маврикия Осиповича Вольфа. St. Peterburg Moscow: Publisher M. O. Wolf. 504 c. (in Russian).

Скривеле М. (1983). Скороплодные и урожайные интродуцированные и местные сорта яблони как исходные формы для селекции [Precocious and productive introduced and local cultivars of apple as a source material for breeding]. В сб.: Селекция сортов яблони интенсивного mипа (с. 85-86). Киев. (in Russian).

Скривеле М. (1988). Испитание Эстонских сортов в Латвии [Testing of Estonian cultivars in Latvia]. Научные труды Эстонского НИИ земледелия и мелорации. Сорта плодовых и ягодных культур в Эстонии. Таллин (in Russian).

Скривеле М., Димза И. (1969). Возможности применения алфанатилуксусной кислоты и ее производных для нормирования урожая яблони [Possibilities of using alpha-naphtylacetic acid and it derivatives for thinning of apple yield]. В сб.: Химическая регуляиия роста и развития растений. (с. 111-129). Рига: Зинатне (in Russian).

Эйхе М. (1976). Изучение глеоспориозных гнилей яблок при хранении и разработка мер борьбы с ними [Investigation of Gloeosporium caused rot on apple during storage and restriction method for its development]. Автореферат диссертации (Doctoral thesis). Москва. 25 с. (in Russian).

Эйхе М., Апените И., Ранцане Р., Цинитис Р. (2005). Болезни и вредители крупноплодной клюквы в Латвии [Diseases and pests of large fruited cranberry in Latvia]. В кн.: Материаль международной научно практической конференции, 9-12 август, 2005 (с. 149-154). Самохваловичи - Минск (in Russian).

\section{AUGL,KOPĪBAS ZINĀTNES ATTĪSTĪBA LATVIJĀ}

Aug̣̣kopība un aug̣̣kopības zinātne Latvijā allaž bijušas cieši saistītas ar visas valsts attīstību. Pēc neatkarības iegūšanas 1918. gadā aug̣̣kopība strauji attīstījās. Lai gan padomju varas gados situācija kvalitatîvu auglu ražošanai nebija labvēlīga, pētniecība un selekcija turpinājās ar labiem rezultātiem. Kad Latvija atguva neatkarību un tika atjaunots privātīpašums uz zemi, strauji pieauga interese par intensīvu dārzu ierīkošanu un mūsdienīgu tehnoloğiju ieviešanu, un tas prasīja mainīt pētījumu virzienu. Pašlaik Latvijas Valsts augḷkopības institūts ir vadošā zinātniskā iestāde šajā laukā, strādājot ciešā sadarbībā ar Pūres Dārzkopības pētījumu centru, Latvijas Lauksaimniecības universitātes Agrobiolog̣ijas institūtu, Pārtikas tehnolog̣ijas fakultāti un Latvijas Universitātes Biolog̣ijas institūta Augu minerālās barošanās laboratoriju. 